\title{
A Descriptive Study of Gender Difference in Digit Ratio among Bini Ethnic Group of southern Nigeria
}

\author{
John N. Paul ${ }^{1 *}$, Deborah A. Akinola ${ }^{1}$, Chibuike Obiandu ${ }^{2}$ \\ ${ }^{I}$ Department of Anatomy, Faculty of Basic Medical Sciences, College of Health Sciences, University of Port \\ Harcourt, Nigeria \\ ${ }^{2}$ Department of Physiology, Faculty of Basic Medical Sciences, College of Health Sciences, University of Port \\ Harcourt, Nigeria
}

*Corresponding Author: John N. Paul, Department of Anatomy, Faculty of Basic Medical Sciences, College of Health Sciences, University of Port Harcourt, Nigeria, Email: nwolim_paul@ uniport.edu.ng

\begin{abstract}
Background: This study investigated gender variation in digit ratios of the Bini ethnic group. The study had a descriptive cross-sectional design with volunteer's age ranging from 18-60 years. For the purpose of this study, an individual was considered to be a Nigeria of a particular ethnic group if the parents and four grandparents are of the same ethnic group.
\end{abstract}

Materials and Methods: Cluster sampling method was used for the study. The selection and collection of required parameters relied on informed consent of volunteers. This was done by giving them a copy of the informed consent letter which was signed and dated. A total of 400 subjects (225 males, 175 females) subjects were recruited for the study. The fingerprints were obtained using print scanner (Hp G3110 Photo scanner).

Results and Discussion: Descriptive statistics of digit length of Bini ethnic group. In the males the following

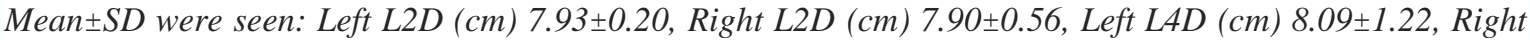

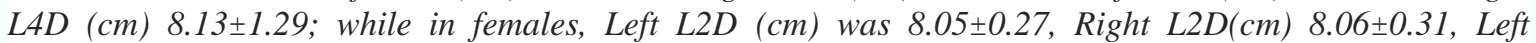
LAD $(\mathrm{cm}) 8.10 \pm 1.19$, Right L4D(cm) 8.12 \pm 1.21 . The males had the Left Digit Ratio 0.98 \pm 0.03 , Right Digit

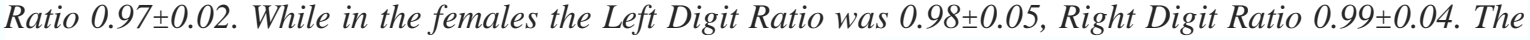
comparison between both sexes were significant with $p=0.001$.

Conclusion: The Bini ethnic group has shown a marked difference in the digit ratio between both sexes. The shorter digit length and a lower digit ratio in males are considered to be typical masculine features, as such could be used as a marker for gender differentiation in a forensic investigation.

Keywords: Gender, Digit Ratio, Bini, Southern, Nigeria.

\section{INTRODUCTION}

Digit ratio is defined as the ratio of the second digit length (2D) to the fourth digit length (4D) of the hand. [1]

\section{Digit Ratio $=\frac{2 D}{4 D}=\frac{\text { Length of the second digit of the finger }}{\text { Length of the fourth digit of the finger }}$}

There are divers works on digit ratio as a subject matter insinuating that it expresses dimorphism in sexes. If this is true, it means that it could serve as a means of identification in forensic and population studies. Digit ratio has also been used to investigate interpopulation affinity stating tribal or population similarity. [2]
It has been speculated that sexual differences in 2D:4D are mainly caused by the shift along the common allometric line with non-zero intercept, which means 2D:4D necessarily decreases with increasing finger length, and the fact that men have longer fingers than women (which may be the basis for the sex difference in digit ratios and/or any putative hormonal influence on the ratios [3-5].

This gender difference has not been investigated amongst Bini tribe before, as such the study was done to know whether the ethnic group under investigation has this feature has have been reported by other authors. This study will add to the body of knowledge information on the 
population characteristics of the indigenous populations especially in Sub-Saharan Africa.

The Edo or Bini (from the word "Benin") people are an ethnic group primarily found in Edo State, and spread across the Delta and Ondo states of Nigeria. They speak the Edo languages and are the descendants of the founders of the Benin Empire. They are closely related to other ethnic groups that speak Edo languages, such as the Esan, the Anemia and the Owan. They have been estimated to have a population of 2,208,700 million [6-8]. There are some reports on investigations by other researchers on digit ratios in various indigenous populations. [9-20]

There is paucity of information on gender difference in digit ratio in Bini tribe.

\subsection{Aim and Objective}

This study was aimed at gender variation in digit ratio of the Bini ethnic group.

\subsection{Scope of the Study}

This study was done specifically on the secondand fourth-digit lengths.

\subsection{Significance of the Study}

This study will benefit the body of knowledge on population studies of ethnic groups in Nigeria which will be significant to historians, sociologists, anthropologists, and the Bini people of Nigeria specifically.

\section{MeTHODS}

\subsection{Research Design}

The study was descriptive and cross-sectional. For the purpose of this study, an individual was considered to be a Nigeria of a particular ethnic group if the parents and four grandparents are of the same ethnic group. Volunteers with age ranging from 18-60 years from the Bini extractions were recruited for this study by purposive sampling. The study was conducted from March 6- October 20, 2019.

\subsection{Data Collection}

The lengths of the second and fourth digits of the left and right hands were measured on the ventral (inferior) surface of the hand from the basal crease of the 2nd and 4th digits to the tip of the finger of the subjects. In situations where there was a band of creases at the base of the digit, the most proximal crease was used. All measurements were done with a digital vernier caliper having an accuracy of $\pm 0.2 \mathrm{~mm}$ [1-3]. The measurements were done three times and the average value was recorded. The lengths of the second digits were divided by the lengths of the fourth digits to obtain the digit ratios [1-3].

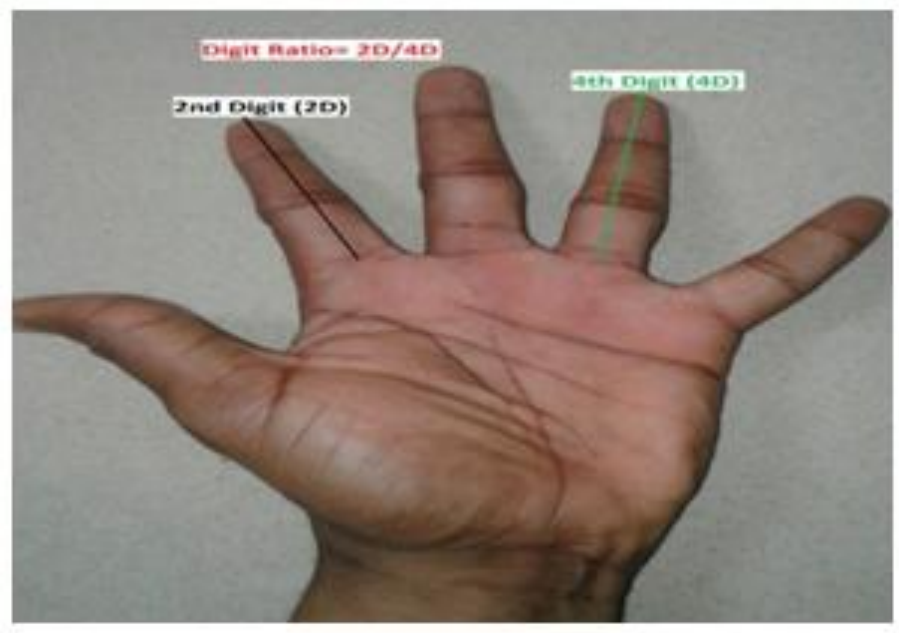

Figure 1: Digit ratio measurement from the study

\subsection{Data Analysis}

The data obtained were analysed using SPSS version 21; independent t-test was used to determine the mean values and comparison between both sexes.

\subsection{Criteria for Subject Selection}

Volunteers recruited were indigenes of the ethnic groups under investigation with no form of anatomical abnormality of the hands.

\subsection{Ethical Consideration}

Ethical clearance was obtained from the Research Ethics Committee of the University of Port Harcourt with REC Number: UPH/CEREMAD/REC/MM59/036before commencement of the study.

\section{Results}

In table 1, descriptive statistics of digit length of Bini ethnic group. In the males the following 
Mean \pm SD were seen: Left L2D $(\mathrm{cm}) 7.93 \pm 0.20$, Right L2D (cm) 7.90 \pm 0.56 , Left L4D (cm) $8.09 \pm 1.22$, Right L4D (cm) $8.13 \pm 1.29$; while in females, Left L2D (cm) was $8.05 \pm 0.27$, Right L2D (cm) 8.06 \pm 0.31 , Left L4D (cm) 8.10 \pm 1.19 , Right L4D (cm) 8.12 \pm 1.21 .
In table 2, the males had the Left Digit Ratio $0.98 \pm 0.03$, Right Digit Ratio 0.97 \pm 0.02 . While in the females the Left Digit Ratio was $0.98 \pm 0.05$, Right Digit Ratio 0.99 \pm 0.04 . In table 3, the comparison between both sexes were significant with $\mathrm{p}=0.001$.

Table 1: Descriptive statistics of digit lengths of Bini ethnic group

\begin{tabular}{|l|l|l|}
\hline \multicolumn{2}{|c|}{ BINI ETHNIC GROUP } \\
\hline \multirow{2}{*}{ Parameters } & Male $[\mathrm{N}=225]$ & Female $[\mathrm{N}=175]$ \\
\cline { 2 - 3 } & Mean \pm SD & Mean \pm SD \\
\hline Left L2D $(\mathrm{cm})$ & $7.93 \pm 0.20$ & $8.05 \pm 0.27$ \\
\hline Right L2D $(\mathrm{cm})$ & $7.90 \pm 0.56$ & $8.06 \pm 0.31$ \\
\hline left L4D $(\mathrm{cm})$ & $8.09 \pm 1.22$ & $8.10 \pm 1.19$ \\
\hline Right L4D $(\mathrm{cm})$ & $8.13 \pm 1.29$ & $8.12 \pm 1.21$ \\
\hline
\end{tabular}

L2D $(\mathrm{cm})<$ L4D $(\mathrm{cm})$, Females $>$ Males

Table 2: Descriptive statistics of digit ratios of Bini ethnic group

\begin{tabular}{|l|l|l|}
\hline \multicolumn{3}{|c|}{ BINI ETHNIC GROUP } \\
\hline Parameters & Male [N = 225] & Female $[\mathrm{N}=175]$ \\
\cline { 2 - 3 } & Mean \pm SD & Mean \pm SD \\
\hline Left L2D $(\mathrm{cm})$ & $0.98 \pm 0.03$ & $0.99 \pm 0.04$ \\
\hline Right L2D $(\mathrm{cm})$ & $0.97 \pm 0.02$ & $0.99 \pm 0.03$ \\
\hline
\end{tabular}

L2D $(\mathrm{cm})<$ L4D $(\mathrm{cm})$, Females > Males

Table 3: Comparison between both sexes in Bini ethnic group

\begin{tabular}{|l|l|l|l|l|}
\hline \multicolumn{1}{|c|}{ Parameters } & \multicolumn{1}{|c|}{ Male [N = 225] } & \multicolumn{1}{|c|}{ Female [N =175] } & \multicolumn{1}{c|}{ t(p-value) } & \multicolumn{1}{c|}{ Inference } \\
\hline Left L2D $(\mathrm{cm})$ & $0.98 \pm 0.03$ & $0.99 \pm 0.04$ & $10.134(0.001)$ & Significant \\
\hline Right L2D $(\mathrm{cm})$ & $0.97 \pm 0.02$ & $0.99 \pm 0.03$ & $12.835(0.001)$ & Significant \\
\hline
\end{tabular}

$\mathrm{P}<0.05$

\section{Discussions}

The ability to distinctively tell the difference between males and females is a desired feature of an anthropological study. The result of the study depicted sexual dimorphism in the digit ratios with the females having higher digit ratios than the males. This dimorphism could have beena result of the difference in androgen level between both genders. The more exposure to testosterone, the lower the digit ratio. This further strengthens what has been reported in the digit lengths. The result of this present study agrees strongly with the reports of previous investigators who have expressly stated that there is sexual dimorphism in the digit ratios. [9$14]$ in this study, it was found that the males repeatedly had low digit ratios compared to the females.

This low digit ratio seen in men is considered a positive trait as several other authors who have worked on this subject reported that low digit ratios are typical masculine traits. Alonso et al. [15] reported that low digit ratio correlates with high social preference. Again, Aycinena et al. [16] in his study asserted that women with low digit ratio tend to be more patient; motioned that a low digit ratio positively correlates with static and explosive strength, speed and agility which is a typical masculine trait exemplified in digit ratio. Furthermore, it was also mentioned that a study on sports activities showed that those who got to the highest level of competition in their respective games had low digit ratios [17] which were mostly men. All these reports from the previous authors affirm the results got from this present study which showed that males had lower digit ratios than the females.

\section{CONClusion}

The Bini ethnic group has shown a marked difference in the digit ratio between both sexes. The shorter digit length and a lower digit ratio in males are considered to be typical masculine features, as such could be used as a marker for gender differentiation in a forensic investigation.

\section{ACKNOWLEDGEMENTS}

We want to appreciate the entire management and staff of the Department of Anatomy, University of Port Harcourt.

\section{REFERENCES}

[1] ManningJTand Robert T. Sexual dimorphism in the 2nd and 4th digit ratio. Hormone and Behaviour, 2002; 24:p. 56-60. 
[2] Manning JT. resolving the role of prenatal sex steroids in the development of digit ratio. 2011; 108:p.16143-4.

[3] Manning JT, Scutt D, Wilson J, and LewisJones DI. "The ratio of 2 nd to 4 th digit length: a predictor of sperm numbers and concentrations of testosterone, luteinizing hormone and oestrogen,"Human Reproduction, 1998; 13(11):p.3000-3004.

[4] Manning JT, Word S, Vang E, Walton J, Bundred PE, Heyningen VC, Lewis-Jones DT. Second to fourth digit ratio (2D:4D) and testosterone in men. Asian Journal of Andrology. 2004; 6:p. 211-215.

[5] Loehlin JC, McFadden D, Medland SE, Martin NG. Population Differences in Finger-Length Ratios: Ethnicity or Latitude? Archives of Sexual Behavior.2006; 35 (6):p.739-742.

[6] John Nwolim Paul*, Gabriel S. Oladipo and Loveday E. Oghenemavwe. Investigation of Ancestral Relationship of Ikwerres' with Binis' and Igbos' Using Level 2 Dermatoglyphic (Minutiae) Patterns. International Journal of Pharma Research and Health Science. 2019; 7 (5):p.3043-3046.

[7] John Nwolim Paul, Gabriel Sunday Oladipo, Loveday Ese Oghenemavwe. Investigation of Prevalence Pattern of Axial Triradii in the Ikwerres', Binis' and Igbos'. Saudi Journal of Biomed Research. 2019; 4(10): p.349-354.

[8] John Nwolim Paul*, Deborah Abosede Akinola, Favour O. Erezih. Descriptive Crosssectional Study of Minutiae Patterns in the Bini People ethnic group of Nigeria. International Journal of Research and Scientific Innovation. 2019; 6(12):p.19-22.

[9] Oladipo GS, Fawehinmi HB, Edibamode EI, Osunwoke EA and Ordu KS. Second to fourth digit ratio in Nigerian Igbos and Yorubas. Scientific Research and Essay, 2009; 4(10):p.1 146-1148.

[10] Gwunireama Israel U, Osunwoke EA, OrishChinna N. Anthropometrical study of 2 nd to 4 th digit ratio of Andoni (Obolo) groups of Ijaw ethnic nationality in Nigeria. International e-Conference on Biomedical, Environmental \& Nutritional Health Sciences. 2009; 4(3):p. 1460-1465.

[11] Gwunireama Israel $U$ and Ihemelandu EC. Geographical influence on digit ratio (2D:4D): a case study of Andoni and Ikwerre ethnic groups in Niger delta, Nigeria. International e-
Conference on Biomedical, Environmental \& Nutritional Health Sciences. 2009; 1461.

[12] Gwunireama IU, Ihemelandu EC. Geographical Influence on Digit Ratio (2D:4D): A CaseStudy of Andoni and Ikwerre Ethnic Groups in Niger delta, Nigeria. Journal of Applied Biosciences 2010; 27:p. 1736 - 1741.

[13] Kullman JA,Pamphlett R. Does the Index-toRing Finger Length Ratio (2D:4D) Differ in Amyotrophic Lateral Sclerosis (ALS)? Journal of Biomedical Sciences. BMJ Open: 2017; 7:e016924.

[14] Lu H, Shen D, Wang L, Niu S, Bai C, Ma Z, Huo Z. Study on the Digit Ratio of Hui and Han Ethnic Groups in Ningxia Acta AnatomicaSinica2008; 15(9):p.176-179.

[15] Alonso J, Di Paolo R, Ponti G,Sartarelli M. Facts and Misconceptions About 2D:4D, Social and Risk Preferences. Journal Frontiers in Behavioural Neurosciences. 2018;12:p. 22.

[16] Aycinena D, Rentschler L. Discounting and Digit Ratio: Low 2D:4D Predicts Patience for a Sample of Females; Journal of Frontiers for Behavioural Neuroscience. 2018; 11(8):p.253- 257.

[17] Meggs J, Chen M,Mounfield D. The Organizational Effect of Prenatal Testosterone upon Gender Role Identity and Mental Toughness in Female Athletes. Journal of Women in Sport and Physical Activity. 2018; 5(2):p.10.

[18] Lutchmaya, S; Baron-Cohen, S; Raggatt, P; Knickmeyer, R; Manning, JT. (2004) "2nd to 4th digit ratios, fetal testosterone and estradiol". Early Human Development 77 (1-2):p. 23-8.

[19] Warrington, NM; Shevroja, E; Hemani, G; Hysi, PG; Jiang, Y; Auton, A; Boer, CG; Mangino, M; Wang, CA; Kemp, JP; McMahon, G; Medina-Gomez, C; Hickey, M; Trajanoska, K; Wolke, D; Ikram, A; Montgomery, GW; Felix, JF; Wright, MJ; Mackey, DA; Jaddoe, VW; $\quad$ Martin, NG; Tung, JY; Smith, GD; Pennell, CE; Spector, TD; van Meurs, J; Rivadeneira, F; Medland, SE; Evans, DM. Genome-Wide Association Study Identifies Nine Novel Loci for 2D:4D Finger Ratio, a Putative Retrospective Biomarker of Testosterone Exposure in Uterus. Journal of Human Molecular Genetics 2018; 27 (11):p.20 25-2038.

[20] Richards G, Bellin W, and Daviesc W. Familial digit ratio (2D:4D) associations in a general population sample from Wales. Early Human Development, 2017; 112: p.14-19.

Citation: John N. Paul, Deborah A. Akinola, Chibuike Obiandu, A Descriptive Study of Gender Difference in Digit Ratioamong Bini Ethnic Group of southern Nigeria. ARC Journal of Forensic Science. 2019 4(2):16-19. http://dx.doi.org/10.20431/2456-0049. 0402004.

Copyright: (C) 2019 Authors. This is an open-access article distributed under the terms of the Creative Commons Attribution License, which permits unrestricted use, distribution, and reproduction in any medium, provided the original author and source are credited. 